\title{
THE NORTHERN FOREST UNION
}

Up to 1939 there was a growing co-operation in Forestry between the Northern Countries: Denmark, Finland, Norway and Sweden. Every third year a northern forest congress was held; 1931 in Norway, 1934 in Denmark, 1937 in Sweden; and there were arrangements made for one in 1940 in Finland but it was cancelled due to the war.

At a conference held in Copenhagen on May 28, 1946, this co-operation was revived and organized through the establishment of a Northern Forest Union. The constitution of this union was drawn up by a board of repre. sentatives of the state forest services, forest owners associations, silvicultural societies, forest research stations and the forest schools in Denmark, Finland, Norway and Sweden.

According to the constitution the object of the Northern Forest Union is to:

(a) Exchange knowledge in all fields of forestry and

(b) Convey to those engaged in forestry in one country further knowledge of forestry in the other countries.

It is proposed to effectuate these objectives by:

(1) Organizing systematic co-operation between forest institutes and forest associations.

(2) Arranging meetings and excursions for those engaged in forestry in the Northern Countries.

(3) Sponsoring writing and publication of bulletins, papers and periodi. cal reviews of forest literature in the forestry journals.

(4) Selecting lecturers from one country to lecture on special topics at the forestry meetings in the other countries.

(5) Sponsoring exchange of forestry students between the Northern Countries.

To administer these activities there was formed a board of four delegates (one from each country) under a chairman who also acts as president of the union. The period of presidency is three years. As president for the first triennial period the Danish delegate, Professor Dr. A. Howard Gron was elected.

The office of the Secretary General for the Northern Forest Union has been established in Copenhagen (Dansk Skovforening, Vester Voldgade 86. Kobenhavn V.) Branch offices have been established in Finland (Generaldirektor, Dr. M. Lappi-Seppala, Forststyrelsen, Helsinki), in Norway (Skogskonsulent $N$. Thlen, Det. Norske Skogselskap, Wergelandsveien 3 B, Oslo) and in Sweden (Byrachef F. Aminoff, Svenska Skogsvardsforeningen, Regeringsgatan 18, Stockholm).

In so far as anyone in other countries desires information on Northern Forestry the Secretary General of the Northern Forest Union as well as the Branch Secretaries will be pleased to forward particulars. 